\title{
A STUDY OF DETERMINANTS IMPACTING LIFE INSURANCE CONSUMPTION WITH REFERENCE TO AHMEDABAD CITY
}

\author{
Dhaval Nakum \\ Research Scholar, \\ S.D. School of Commerce, Gujarat University \\ dhavalnakum@ymail.com
}

\begin{abstract}
Paper investigates how various demographic factors influence the life insurance consumption. Life insurance is complex and abstract service that has become an essential part of individual's future planning and safety by offering a diverse variety of policies. What are the major factors that influence the purchase of life insurance? Research hypotheses are tested empirically using chi-square test and the results of study are based on nearly three hundred responses from Ahmedabad city. Paper finds that educational background, occupation and annual income are significant demographic variables where as no association found between age and consumption of life insurance.
\end{abstract}

Key words: Life insurance consumption, demographic variables, determinants of life insurance

\section{INTRODUCTION}

Every individual, as a human being, is at risk from one or more sources. At the same time, as a person, he has responsibilities to meet. Emotional factors have an effect on Indian consumers. At the same time, objective considerations affect their purchasing decisions. A typical Indian believes in the future and strives to have a better and more stable future for his family. Each rupee earned will be used to help the person lead his or her family in the present and for a better life in the future. Both the risk coverage and the saving aspects are covered by life insurance. Since the majority of citizens in the economy are middle-class and salaried, insurance has emerged as the best choice for saving and risk protection. Demographic shifts would radically alter the types of customers that insurers must seek, as well as the products they must provide. State pensions and social services such as public hospitals will be strained as the age of population increases. A higher proportion of the population living in cities puts them at greater risk of illness due to pollution, poor hygiene, and other urban lifestyle factors.

\section{REVIEW OF LITERATURES}

Several authors have developed theoretical models on consumption of life insurance. The demand for life insurance is attributed to a person's desire to bequeath funds to dependents and also provide income for retirement. For several years, insurance research has focused on the factors that affect life insurance consumption. Numerous variables have been identified in studies as potentially important in understanding life insurance consumption.

Campbell (1980) found that primary driver of life insurance purchases is the need to shield dependents from financial distress. Chui and Kwok (2008) discovered that as a person's dependents increase, he or she will need to purchase more life insurance.

Outreville (1996) found that education extends the period of dependence. As a result, there may be a higher demand for life insurance in groups where individuals are educated over a longer period of time. Beck and Webb (2003) concluded that an individual's ability to recognize the advantages of risk management and savings can be determined by his or her level of education, a higher level of education may contribute to a greater degree of risk aversion and greater understanding of the importance of insurance in general.

Age is found to be positively significant in studies of Ferber and Lee (1980), Bernheim (1991) and Chen et al. (2001).

As per studies of Miller (1985) retirees have less life insurance than active employees of the same age, so employment (social) status is expected to be positively related to life insurance demand. 


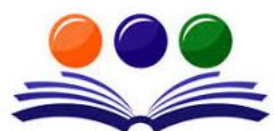

GRAND ACADEMIC PORTAL RESEARCH JOURNALS
A GLOBAL JOURNAL OF SOCIAL SCIENCES

( ISSN - 2581-5830 )

Impact Factor - SJIF - 4.998, IIFS - 4.375

Globally peer-reviewed and open access journal.

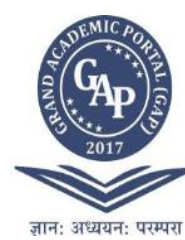

In the majority of studies, income remained a key determinant of life insurance demand (Browne and Kim, 1993; Babbel, 1985; Beenstock et al. 1989; Outveville, 1996). Higher income improves not only people's standard of living, but also their savings. Life insurance becomes more affordable as one's income rises.

\section{RESEARCH GAP}

From the previous studies it was found that age, number of dependents, income, education and occupation are major demographic determinants of life insurance demand and consumption. Life insurance consumption pattern was not studied extensively with demographic profile in Ahmedabad city.

\section{RESEARCH METHODOLOGY}

\section{Objective of the study}

The aim of this study is to determine which demographic factors influence life insurance consumption in Ahmedabad city.

\section{Scope of the study}

There can be demographic, economic, institutional determinants of life insurance consumption. This study is limited to only four demographic determinants of life insurance consumption.

\section{Hypotheses of the study}

H01: There is no significant association between age and consumption of life insurance.

$\mathbf{H O}_{2}$ : There is no significant association between educational background and consumption of life insurance.

$\mathbf{H O}_{3}$ : There is no significant association between occupation and consumption of life insurance.

HO$_{4}$ : There is no significant association between annual income and consumption of life insurance.

\section{Sampling method}

Convenience sampling technique was adopted for the purpose of study.

\section{Data collection}

Primary data was collected for this study with the help of questionnaire via SurveyMonkey online survey platform.

\section{Sample size}

A total of 290 responses were collected from different areas across Ahmedabad city.

\section{Tools and techniques}

Following tools and techniques were used in the study:

1. Microsoft Office Excel 2016

2. IBM SPSS Statistics 23

3. SurveyMonkey

4. Chi-square test

\section{Limitations of the study}

Study is restricted to Ahmedabad city only and even sample size is too low compared to population of the study. Only few demographic variables are selected for this study. As this study is based on primary data, all the limitations of primary data will be applicable to present study also.

\section{DATA ANALYSIS}

To analyze the above-mentioned hypotheses, chi-square test is applied and obtained results were presented in the below table.

\begin{tabular}{|l|c|c|c|c|}
\hline $\begin{array}{l}\text { Demographic variable - Life } \\
\text { insurance consumption }\end{array}$ & Value & $\begin{array}{l}\text { Degree of } \\
\text { Freedom }\end{array}$ & $\begin{array}{l}\text { Asymp. Sig. (2- } \\
\text { sided) }\end{array}$ & $\begin{array}{l}\text { Decision about Null } \\
\text { Hypothesis }\end{array}$ \\
\hline Age & 8.426 & 4 & 0.077 & Accepted \\
\hline Educational background & 44.874 & 5 & 0.000 & Rejected \\
\hline Occupation & 11.572 & 4 & 0.021 & Rejected \\
\hline Annual income & 43.564 & 3 & 0.000 & Rejected \\
\hline
\end{tabular}




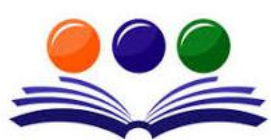

GRAND ACADEMIC PORTAL RESEARCH JOURNALS

A GLOBAL JOURNAL OF SOCIAL SCIENCES

( ISSN - 2581-5830)

Impact Factor - SJIF - 4.998, IIFS - 4.375

Globally peer-reviewed and open access journal.

From the above table it can be deduced that null hypothesis for age and consumption of life insurance is failed to be rejected as $p$ value is higher than standard value of 0.05 means there is no association between age and consumption of life insurance. The outcome of this hypothesis is consistent with Gandolfi and Miners (1996). Null hypothesis for educational background and consumption of life insurance is rejected as $p$ value is less than standard value of 0.05 means there is significant association between educational background and consumption of life insurance. Education increases the ability to understand the benefits of risk management and necessity of life insurance. Result of this hypothesis is in line with study of Li et. al., (2007).

Null hypothesis for occupation and consumption of life insurance is rejected as p value is 0.021 which is less than standard $p$ value means there is significant association between occupation and life insurance consumption. To discover how occupation can be one of the determinants of life insurance consumption, further in depth analysis is required.

Annual income of the family is key determinant in life insurance consumption. Most of the previous studies had suggested that income had positive and significant association with demand of life insurance. In present study also it is found that null hypothesis for annual income and consumption of life insurance is rejected means there is significant association between annual income and life insurance consumption.

\section{FINDINGS AND CONCLUSION}

It is obvious that income has remained key determinant in consumption of life insurance in India because of prevalent income tax laws. There are certain tax deductions available in income tax. People purchase life insurance policies to reduce their tax liability. Investments, risk coverage and income tax deductions benefits are the three purposes served together by consuming life insurance. Consumption of life insurance has risen as individual's education levels have risen. Financial literacy plays important role in managing risk. Age and insurance premium has direct relationship. Amount of premium increases with the increment in age of individual. Therefore, further research is needed to understand why there is no association between age and life insurance consumption. Decision to buy life insurance products is not taken only on the basis of present financial position as amount of premium is required to pay for longer time period.

\section{REFERENCES}

[1] Campbell, R.A., 1980, The Demand For Life Insurance: An Application Of The Economics Of Uncertainty, The Journal Of Finance. vol. 35, no. 5, pp. 1155-1172.

[2] Chui, A.C.W., and C.C.Y. Kwok, 2008, National Culture and Life Insurance Consumption. Journal of International Business Studies. vol. 39, no. 1, pp. 88-101.

[3] Outreville, J.F., 1996, Life Insurance Markets in Developing Countries. The Journal of Risk and Insurance. vol. 63, no. 2, pp. 263-278.

[4] Beck, T., and I. Webb, 2003, Economic, Demographic, And Institutional Determinants of Life Insurance Consumption across Countries. World Bank Economic Review. vol. 17, no. 1, pp. 51-88.

[5] Ferber, R., and L.C. Lee, 1980, Acquisition and Accumulation of Life Insurance in Early Married Life. The Journal of Risk and Insurance. vol. 47, no. 4, pp. 132-152.

[6] Bernheim, B.D., 1991, How Strong Are Bequest Motives? Evidence Based On Estimates of the Demand for Life Insurance and Annuities. Journal of Political Economy. vol. 99, no. 5, pp. 899-927.

[7] Chen, R., and K.A. Wong, and H.C. Lee, 2001, Age, Period, and Cohort Effects on Life Insurance Purchases in the U.S. The Journal of Risk and Insurance. Vol. 68, no. 2, pp. 303 - 327.

[8] Miller, M.A., 1985, Age-Related Reductions in Workers's Life Insurance. Monthly Labor Review. pp. 29-34.

[9] Browne, M.J. and K. Kim, 1993, An International Analysis Of Life Insurance Demand. The Journal of Risk and Insurance. vol. 60, no. 4, pp. 616-634.

[10] Babbel, D.F., 1985, The Price Elasticity Of Demand For Whole Life Insurance. The Journal of Finance. vol. 40, no. 1 , pp. 225-239.

[11] Beenstock, M., and Dickinson, G., and S. Khajuria, 1989, The Determination Of Life Premiums: An International Cross-Section Analysis 1970 - 1981. Insurance: Mathematics and Economics. 1989. vol. 5, no. 4, pp. 261-270.

[12] Gandolfi, A. S. and L. Miners, 1996, Gender-Based Differences in Life Insurance Ownership. The Journal of Risk and Insurance. vol. 63, no. 4, pp. 683-693.

[13] Li, D., and Moshirian, F., and Nguyen, P., and T. Wee, 2007, The Demand For Life Insurance In OECD Countries. The Journal of Risk and Insurance. vol. 74, no. 3, pp. 637-652. 